experience deepens the user's understanding of the complicated 3D protein structure and elucidates ligand binding and protein-protein interactions. This model would be an effective discussion tool for the classroom or laboratory that stimulates inspired learning in this study field.

\section{PT137 蛋白質熱安定性に及ぼす榶の影餢}

Effects of sugars on the thermal stability of proteins

Hiraku Oshima ${ }^{1}$, Ken-ichi Amano ${ }^{2}$, Masahiro Kinoshita' ('Inst. Adv. Energy, Kyoto Univ., ${ }^{2}$ Dep. Chem., Kobe Univ.)

It is experimentally known that the heat-denaturation temperature of a protein $T_{\mathrm{m}}$ is raised by the sugar addition. The magnitude of this effect stabilizing the protein depends on the sugar species [1]. In earlier work, we proposed a measure of the thermal stability of a protein, which is defined as the solvent-entropy gain at $298 \mathrm{~K}$ upon protein folding $S$ normalized by the number of residues [2,3]. $S$ was calculated using a hybrid of the angle-dependent integral equation theory combined with the mulipolar water model and the morphometric approach. Here we show that $S$ can be calculated using the hard-sphere solvent whose number density and molecular diameter are set at those of water. We then investigate the effects of sugar addition on the thermal stability by considering water-sugar solution modeled as a binary mixture of hard spheres. The three-dimensional integral equation theory is employed. The thermal stability is determined by a complex interplay of the molecular size of the sugar $D$ and the total packing fraction of the solution $\eta$. $D$ is estimated from the volume per molecule in the sugar crystal, and $\eta$ is calculated using the experimental data of the solution density. We find that the thermal stability is considerably enhanced by addition of sucrose. In the presentation, we will discuss the effects of addition of not only sugars other than sucrose but also osmolytes.

[1] J. F. Back, Biochemistry 18 (1979) 5191.

[2] K. Amano et al., Chem. Phys. Lett. 474 (2009) 190.

[3] K. Oda et al., J. Chem. Phys. 134 (2011) 025101.

\section{$1 \mathrm{PT} 138$ ヒトカルシトニンアミロイド線維形成阻害機構の解析}

Amyloid fibril inhibition mechanism of human calcitonin

Naoharu Kouduki ${ }^{1}$, Hironari Kamikubo ${ }^{1}$, Tomoyasu Aizawa ${ }^{2}$, Yoko Ogawa ${ }^{3}$ Yoichi Yamazaki Yoichi Yamazaki ${ }^{1}$, Mariko Yamaguchi ${ }^{1}$, Mikio Kataoka ${ }^{1}$ ( ${ }^{1}$ Grad. Sch. Mat. Sci., NAIST, ${ }^{2}$ Graduate School of Life Science, Hokkaido University, ${ }^{3}$ Osaka University of Pharmaceutical Sciences)

Human calcitonin (hCT) is a 32-residue peptide hormone. $\mathrm{hCT}$ is used as a medicine for osteoporosis, but it easily forms amyloid fibrils under physiological condition, which is a problem on medication. Salmon calcitonin (sCT) is known to inhibit amyloid formation of hCT. Combinational use of hCT and $\mathrm{sCT}$ is expected to improve the pharmacological activity. While the $\mathrm{N}$ terminal region (9-19) of sCT takes an $\alpha$-helix, the C-terminal half of the helix is disordered in hCT. Although an interaction between the disordered region and the $\mathrm{C}$-terminal tail of $\mathrm{hCT}$ is proposed to play a role on the amyloid formation, the detailed mechanism of the inhibition of the amyloid formation by SCT has not been revealed. In this study, we investigated amyloid fibril formation of hCT in the presence of each of two chimera peptides, which are comprised of the 115residues of hCT and the 16-32residues of $\mathrm{sCT}$ and, the reverse combination. The former region (1-15) contains the stable $\alpha$-helix and the latter the flexible region in hCT. Amyloid fibril formation was monitored by fluorescence intensity from Thioflavin $\mathrm{T}$. While the fluorescence intensity raised about $30 \sim 40$ hours after incubation of hCT alone, the amyloid fibril formation was inhibited in the presence of sCT, or each of the two chimera peptides, indicating that each of the $\mathrm{N}$-terminal and the $\mathrm{C}$-terminal regions of $\mathrm{sCT}$ possesses the inhibitory ability. From these results, we conclude that both the C-terminal region and the $\mathrm{N}$-terminal stable $\alpha$-helix are engaged in the inhibition of the amyloid formation.

\section{PT139 ダブル pH ジャンプによるアミロイド線維のほぼ可逆的な構造変化 の解析}

Analysis of Almost Reversible Conformational Change of Amyloid Fibrils by Double pH-jump

Keiichi Yamaguchi ${ }^{1}$, Yuji O. Kamatari ${ }^{2}$, Mayuko Fukuoka ${ }^{1}$, Reiji Miyaji ${ }^{3}$, Kazuo Kuwata ${ }^{1}{ }^{1}$ Unit. Grad. Sch. of Drug Dis. and Med. Inf. Sci., Gifu Univ., ${ }^{2}$ Life Sci. Res. Center, Gifu Univ., Sup. and Dev. Center for Tech. Ed., Fac. of Eng., Gifu Univ.)

To obtain insights into the mechanism of amyloid fibril conversion, $\mathrm{pH}$-jump experiments were performed using a $\mathrm{H} 2$ peptide of mouse prion protein. Previously, we reported that $\mathrm{H} 2$ peptide formed ordered amyloid fibrils with an immensely large minimum at $207 \mathrm{~nm}$ on $\mathrm{CD}$ spectrum at $\mathrm{pH} 2.9$ (named $\mathrm{pH} 2.9$ fibrils), but aggregate-like fibrils with a minimum at $220 \mathrm{~nm}$ were formed at $\mathrm{pH}$ 7.5 (named $\mathrm{pH} 7.5$ fibrils) near its isoelectric point. In this study, firstly single pH-jump from 2.9 to 7.5 was performed. As a result, the $\mathrm{CD}$ spectrum showed that the $\mathrm{pH} 2.9$ fibrils instantly changed to $\mathrm{pH} 7.5$-like fibrils with a minimum at $218 \mathrm{~nm}$, but the ellipticities were certainly distinct between $\mathrm{pH} 7.5$-like and $\mathrm{pH} 7.5$ fibrils, implying that the conformation of $\mathrm{pH} 2.9$ fibrils partially remains even at $\mathrm{pH}$ 7.5. Moreover, the $\mathrm{pH} 7.5$-like fibrils almost returned to the $\mathrm{pH} 2.9$ fibrils by restoring the solution $\mathrm{pH}$ from 7.5 to 2.9 . FT-IR spectra indicated that these conformational changes were caused by the disruption of highly ordered $\beta$ -sheet and $\beta$-turn conformations, and the subsequent their reconstructions. In addition, kinetic conformational changes of the fibrils after the single and double $\mathrm{pH}$-jumps were examined using ANS fluorescence stopped-flow. As a result, these conversions of the fibrils composed of a few phases were accomplished within several seconds. Thus, amyloid fibrils can be changed readily between the distinct conformations separated by a low energy barrier almost reversibly.

\section{PT140 金属結合によるヒトプリオンタンパク質のペプチド断片の構造変化}

Conformation change in peptide fragments of human prion protein caused by metal binding

Kazuya Iwama ${ }^{1}$, Takahito Imaki ${ }^{1}$, Masahiro Yagi ${ }^{2}$, Wakako Hiraoka ${ }^{2}{ }^{1}$ Grad. Sch.Sci,Univ.Meiji, ${ }^{2}$ Sch.Sci,Univ.Meiji)

Prion diseases are transmissible spongiform encephalopathies (TSE) and lethal infectious diseases caused by misfolding of prion protein (PrP). Human prion protein (huPrP) binds metal ion at the residues 60-91 (His61, His69, His77, His85) and residues 90-126 (His96,His111) in N-terminal. Histidine residue are known as high-affinity sites to metal binding. Metal binding to PrP is considered as an important process for misfolding of $\operatorname{PrP}$. This report aims to investigate conformation change in huPrP caused by metal binding. huPrP Peptide fragments conteining His 96 and/or His 111 were examined for binding metal such as $\mathrm{Cu}^{2+}, \mathrm{Ni}^{2+}$ and $\mathrm{Co}^{2+}$. pKa values were determined with electro titrimetric analysis (Metrohm, 848 titrino plus). Metal binding to peptide fragment was observed using visible absorption spectra (Hitachi, U-2800 Spectrophotometer) and Circular Dichroism (CD)(JASCO,J-820). Secondary structure of peptide fragment was observed using Far-UV CD. Addition of $\mathrm{Cu}^{2+}$ and $\mathrm{Ni}^{2+}$ to huPrP (93-102:GGTHSQWN) showed the shift of $\mathrm{pKa}$ value. Vis absorption and Vis $\mathrm{CD}$ indicated the characteristic spectra resulting from metal binding. It was derived from imidazole $\mathrm{N}$ bound to metal ion and from $\mathrm{d}-\mathrm{d}$ transition of metal ion. Far-UV CD spectrum showed the conformational change of secondary structure induced by metal binding. We will also investigate metal binding to peptide fragments of huPrP containing Hisl11 by using UV/Vis spectroscopy, $\mathrm{CD}$ and electron spin resonance (ESR) to further understand about metal binding to huPrP.

\section{PT141 ユビキチンの温度-圧カ-自由エネルギー地形図}

\section{Temperature-pressure-free energy landscape of ubiquitin}

Tsubasa Yamamoto', Minoru Kato ${ }^{2}\left({ }^{1}\right.$ Graduate school of Life Science, Ritsumeikan University, ${ }^{2}$ Department of Pharmacy, Ritsumeikan University)

To understand the change of packing and/or solvation of protein denaturation from quantitative point, volume change $\Delta V$ and isothermal compressibility change $\Delta \beta_{\mathrm{T}}$, and thermal expansion coefficient change $\Delta \alpha$ are needed. These thermodynamic parameters at given temperature and pressure are determined from temperature $(T)$ - pressure $(p)$ - free energy change $(\Delta G)$ landscape,which is obtained fraom combined series of pressure/temperature variable denaturation experiments.

In this study, we explore the $(T, p, \Delta G)$ landscape of ubiquitin. FTIR spectra of ubiquitin was reversibly changed by temperature/pressure perturbation at $\mathrm{pD} 2.0$ and $\mathrm{pD}$ 5. 5. To determined $\Delta G$ at given temperature and pressure, temperature/pressure transition curves were obtained from change in FTIR peak intensity at $1673 \mathrm{~cm}^{-1}$ which is assigned to native $\beta$-strand structure. Threedimensional $(T, p, \Delta G)$ landscapes and thermodynamic parameters $\left(\Delta V, \Delta \beta_{\mathrm{T}}, \Delta\right.$ $\alpha$, entropy change $\Delta S$ and heat capacity change $\Delta \mathrm{C}_{\mathrm{p}}$, ) at ambient temperature and pressure $(298 \mathrm{~K}, 0.1 \mathrm{MPa})$ were obtained.

\section{PT142Ｘ 線小角散乱によるフェリチンアセンブリ反応の追跡}

Ferritin assembly kinetics followed by small-angle $\mathrm{X}$-ray scattering 